\title{
GENETIC DIVERGENCE STUDIES IN BLACKGRAM (VIGNA MUNGO L.) FOR YIELD AND QUANTITATIVE TRAITS
}

\author{
S. SRI VIDYA, T. SABESAN*, K. SARAVANAN \\ Department of Genetics and Plant Breeding, Faculty of Agriculture, Annamalai University, \\ Annamalai Nagar 608002, Tamil Nadu, India
}

\begin{abstract}
The genetic divergence was estimated in 21 blackgram genotypes, using Mahalanobis $\mathrm{D}^{2}$ statistics. The experiment was conducted at Plant Breeding Farm, Department of Genetics and Plant Breeding, Faculty of Agriculture, Annamalai University during January 2017. Analysis of genetic variance indicated the presence of sufficient variation among the selected genotypes. Based on 11 morphological and quality characters namely, days to first flower, plant height $(\mathrm{cm})$, number of primary branches, number of clusters per plant, number of pods per plant, pod length $(\mathrm{cm})$, pod weight $(\mathrm{g})$, number of seeds per pod, seed size $(\mathrm{cm}), 100$ seed weight $(\mathrm{g})$, yield per plant $(\mathrm{g})$, these genotypes were grouped into 5 clusters showing fair degree of relationship between geographical distribution and genetic divergence. Cluster I, with 6 genotypes, was the largest cluster followed by cluster IV and V with 5 genotypes. The intra cluster distance was maximum $(\mathrm{D}=809.83)$ in cluster V. The maximum inter cluster distance $\left(\mathrm{D}^{2}=2932.162\right)$ was recorded between cluster II and III. All cluster mean values are distributed in relatively distant clusters. Traits like yield per plant (70.47\%) followed by 100 seed weight (17\%) were the major contributors to total genetic divergence.
\end{abstract}

Keywords: Blackgram, Genetic divergence, Quantitative traits, Yield components

\section{INTRODUCTION}

Vigna is an expansive leguminous taxon containing 104 portrayed species conveyed in tropical and subtropical locales of Africa, Asia, America, and Australia [9]. It is a widely cultivated legume in all over the world [3]. Blackgram is an important food legume with excellent source of good quality protein and having ability to restore fertility of soil though symbiotic nitrogen fixation. Though India is the larger producer of blackgram, the productivity is still low. $\mathrm{D}^{2}$ statistic is one of the potent techniques of measuring genetic diversity in plant breeding. Knowledge about genetic diversity is an invaluable aid in crop improvement strategies. The selection of genetically diverged parents is expected to throw superior and desirable segregants following crossing [2]. The hybrids between genetically diverse parents yielded greater heterosis than those between more closely related parents a total of twenty one germplasm accessions of blackgram were subjected to divergence studies by $\mathrm{D}^{2}$ statistic $[14,12]$.

\section{MATERIALS AND METHODS}

The investigation, which consisted of twenty one blackgram genotypes, was carried out during January to April 2017 at the Plant Breeding Farm, Department of Genetics and Plant Breeding, Annamalai University. Eleven quantitative traits viz., days to first flower, plant height $(\mathrm{cm})$, number of primary branches, number of clusters, number of pods per plant, pod length $(\mathrm{cm})$, pod weight $(\mathrm{g})$, number of seeds per pod, seed size (cm), 100 seed weight (g), yield per plant (g). Assessment of genetic divergence was done using Mahalanobis $\mathrm{D}^{2}$ [10] statistic and the genotypes were grouped into different clusters following Tochers method as described [13] using Genres statistical package.

\section{RESULT AND DISCUSSION}

Genetic divergence analysis was carried out by calculating $\mathrm{D}^{2}$ values from the means of 21 genotypes of blackgram for 11 characters. The genotypes were grouped into 5 clusters (table 1). Among the 5 clusters, cluster 1 contains maximum number of 6 genotypes followed by cluster IV and V with 5 genotypes each. Clusters III with 3 genotypes and cluster II with 2 genotypes.

The intra and inter cluster $\mathrm{D}^{2}$ values are presented in the table 2. In the present study, it is indicated that more prominent inter cluster distances when comparing to intra cluster distances and there is genetic diversity shown among the genotypes. Similar reports were reported [15, 14]. Intra cluster distance ranged from 10.30 to 28.46 . Cluster V recorded the maximum intra cluster distance of 28.46. Lowest intra cluster distance was recorded by cluster II (10.30). Higher inter cluster distance which was observed between clusters II and III (54.15) which was followed by clusters III and V (47.55) which indicated the presence of large variation in genotypes. The size of heterosis depends generally on the level of genetic diversity in the parental lines. So, the genotypes from these assorted groups could be utilized as a part of the hybridization to

\section{Received 17 February 2018; Accepted o5 April 2018}

\section{${ }^{*}$ Corresponding Author}

\section{T. Sabesan}

Department of Genetics and Plant Breeding, Faculty of Agriculture, Annamalai University, Annamalai Nagar 608002, Tamil Nadu, India

Email: sabavani@gmail.com

(OThis article is open access and licensed under the terms of the Creative Commons Attribution License (http://creativecommons.org/licenses/by/4.o/) which permits unrestricted, use, distribution and reproduction in any medium, or format for any purpose, even commercially provided the work is properly cited. Attribution - You must give appropriate credit, provide a link to the license, and indicate if changes were made. 
get wide range of hereditary fluctuation in the isolating generation [11]. The least inter cluster distance was found between cluster II and V (24.43) suggested that the genetic constitution of the genotype in one cluster were in close proximity with the genotype in the other cluster of the pair. Hence, genotypes from these clusters may not be useful. This result is supported by earlier findings in blackgram [8,7and6]. The relative contribution of each character towards divergence was represented in table 3. Yield per plant (70.47\%) contributed maximum towards genetic divergence followed by 100 seed weight (17\%).
The contribution of seed size and number of pods per plant were 3.81 and 2.38 respectively. Traits which are responsible for more divergence will be given more priority for the purpose of further selection and the choice of parents for hybridization [5]. The cluster means for the eleven characters are given in table 4, the lowest mean value for days to first flowering was recorded by cluster II. The highest mean value for number of pods per plant was recorded by cluster III and I. Cluster II recorded the highest mean for number of primary branches followed by cluster I. Cluster III recorded the highest mean for pod length and pod weight. Cluster V recorded the highest mean for clusters per plant, hence crossing these genotypes would result in getting transgressive segregants.

Table 1: Composition of $\mathrm{D}^{2}$ clusters for 21 blackgram genotypes

\begin{tabular}{lll}
\hline Clusters & Number of genotypes & Name of Genotypes \\
\hline I & 6 & IC-281994, IC-436811, IC-282004, ABG-11028, VBG-11020, VBG-13019 \\
II & 2 & RU-16-18, RU-16-14 \\
III & 3 & VBG-12039, VBG-11027, VBG-11033 \\
IV & 5 & VBG-12042, RU-16-15, ADT-3, ADT-4, PU-31 \\
V & 5 & Sekar-1, VBN-3, VBN-5, VBN-8, PBG-107 \\
\hline
\end{tabular}

Table 2: Average inter $\left(D^{2}\right)$ and intra (D) cluster distance for 21 blackgram genotypes

\begin{tabular}{llllll}
\hline Clusters & I & II & III & IV & V \\
\hline I & $26.34(693.58)$ & $38.12(1453.06)$ & $33.26(1106.56)$ & $25.24(637.05)$ & $32.57(1061.15)$ \\
II & & $10.30(106.16)$ & $54.15(2932.16)$ & $30.88(953.31)$ & $24.43(596.86)$ \\
III & & $26.99(728.73)$ & $39.43(1554.42)$ & $47.55(2261.12)$ \\
IV & & & $23.67(560.26)$ & $26.51(702.75)$ \\
V & & & & $28.46(809.83)$ \\
\hline
\end{tabular}

Table 3: Contribution of characters to genetic divergence in blackgram

\begin{tabular}{lll}
\hline S. No. & Character & Contribution of characters (\%) \\
\hline 1 & Number of days to first flowering & 0.48 \\
2 & Plant height & 0.95 \\
3 & Number of primary branches & 0.48 \\
4 & Number of clusters per plant & 0.62 \\
5 & Number of pods per plant & 2.38 \\
6 & Pod length & 1.43 \\
7 & Pod weight & 0.95 \\
8 & Number of seeds per pod & 1.43 \\
9 & Seed size & 3.81 \\
10 & 10o Seed weight & 17.00 \\
11 & Yield per plant & 70.48 \\
\hline
\end{tabular}

Table 4: Cluster means of 21 blackgram genotypes for various characters

\begin{tabular}{|c|c|c|c|c|c|c|c|c|c|c|c|}
\hline Clusters & $\begin{array}{l}\text { Number } \\
\text { of days to } \\
\text { first } \\
\text { flowering }\end{array}$ & $\begin{array}{l}\text { Plant } \\
\text { height } \\
\text { (cm) }\end{array}$ & $\begin{array}{l}\text { Number } \\
\text { of } \\
\text { primary } \\
\text { branches }\end{array}$ & $\begin{array}{l}\text { Number } \\
\text { of } \\
\text { clusters } \\
\text { per } \\
\text { plant }\end{array}$ & $\begin{array}{l}\text { Number } \\
\text { of pods } \\
\text { per } \\
\text { plant }\end{array}$ & $\begin{array}{l}\text { Pod } \\
\text { length } \\
\text { (cm) }\end{array}$ & $\begin{array}{l}\text { Pod } \\
\text { weight } \\
\text { (g) }\end{array}$ & $\begin{array}{l}\text { Number } \\
\text { of seeds } \\
\text { per pod }\end{array}$ & $\begin{array}{l}\text { Seed } \\
\text { size } \\
(\mathrm{cm})\end{array}$ & $\begin{array}{l}100 \\
\text { seed } \\
\text { weight } \\
\text { (g) }\end{array}$ & $\begin{array}{l}\text { Yield } \\
\text { per } \\
\text { plant } \\
\text { (g) }\end{array}$ \\
\hline I & 34.83 & 74.79 & 6.83 & 5.75 & 14.72 & 4.41 & 0.37 & 6.22 & 0.36 & 4.12 & 2.88 \\
\hline II & 33.75 & 56.12 & 6.87 & 5.00 & 8.46 & 4.34 & 0.41 & 5.83 & 0.36 & 5.23 & 2.27 \\
\hline III & 35.67 & 100.75 & 5.75 & 6.10 & 20.61 & 4.53 & 0.43 & 5.78 & 0.37 & 4.11 & 4.49 \\
\hline IV & 34.30 & 70.70 & 5.60 & 5.68 & 10.96 & $4 \cdot 31$ & 0.34 & 5.97 & 0.36 & 4.17 & 2.49 \\
\hline $\mathrm{V}$ & 33.90 & 51.95 & 5.05 & 6.39 & 10.76 & 4.38 & 0.39 & 6.17 & 0.36 & 4.50 & 2.20 \\
\hline $\begin{array}{l}\text { General } \\
\text { mean }\end{array}$ & 34.49 & 70.8634 & 6.02 & 5.78 & 13.10 & 4.39 & 0.39 & 5.99 & 0.36 & 4.43 & 2.87 \\
\hline
\end{tabular}




\section{REFERENCES}

1. Ali MN, Gupta S, Bhattacharya S, Sarkar HK. Evaluation of blackgram [Vigna mungo (L.) Hepper] germplasm using multivariate analysis. Environment and Ecology 2008;26 (2A): 943-945.

2. Bhatt GM. Comparison of various methods of selecting parents for hybridization in common bread wheat (Triticum aestivum L). Avst. J. Agri. Sci. 1973;24:457-64.

3. Chandel KPS, Lester RN, Starling RJ. The wild ancestors of urd and mung beans (Vigna mungo (L.) Hepper and V. radiata (L.) Wilczek). Bot. J. Linn. Soc. 1984;89:85-96.

4. Chauhan MP, Mishra AC, Singh AK. Genetic divergence studies in urdbean (Vigna mungo L.). Legume Res. 2008;31: 63-67.

5. Elangaimannan, R., Y. Anbuselvam and $P$. Karthikeyan.2008. Genetic diversity in blackgram (vigna mungo (L.) Hepper). Legume Res., 31:57-59.

6. Kanta G, Verma S. Genetic divergence studies in blackgram. National J. Plant Improvement, 2003;5: 3842.

7. Konda CR, Salimath PM, Mishra MN. Genetic diversity estimation in blackgram. Legume Res. 2007;30: 212-214.
8. Lad DB, Punde PB, Dahake KD. Genetic divergence studies in blackgram. J. Maharashtra Agri. Universities 2005;30:183-186

9. Lewis G, Schrire B, Mackinder B, Lock M. Legumes of the world, Kew Royal Botanic Gardens, Richmond Surrey, 2005. p. 577.

10. Mahalanobis PC. On the generalized distance in statistics. Proc. Nat. Acad. Sci. India, 1936;2:49-55.

11. Punitha, E. 2017. Studies on genetic divergence in blackgram (vigna mungo [L] Hepper) using microsatellite markers. M. Sc., thesis, Annamalai University

12. Ramanujam S, Tiwari AS, Mehra RB. Genetic divergence and hybrid performance in mungbean. Theo. Appl Genet. 1974;45:211-214.

13. Rao CR. Advanced Statistical Methods in Biometric Research. John Wiley and Sons Inc. New York, 1952. pp. $130-34$.

14. Rao CR. Multivariate analysis. An indispensable statistical aid in applied research. Sankhya 1960;22:317-388

15. Singh B. Genetic divergence in blackgram. Legume Res. 2001;24: 54-56. 